\title{
Analisis Kecelakaan Kerja dengan Menggunakan Metode FTA Dan 5s di PT. Jingga Perkasa Printing
}

\author{
Muhammad Nur ${ }^{1}$, Oki Ariwibowo ${ }^{2}$ \\ ${ }^{1,2}$ Jurusan Teknik Industri, Fakultas Sains dan Teknologi, UIN Sultan Syarif Kasim Riau \\ Jl. HR. Soebrantas No. 155 Simpang Baru, Panam, Pekanbaru, 28293 \\ Email: muhammad.nur@uin-suska.ac.id
}

\begin{abstract}
ABSTRAK
PT. Jingga Perkasa Printing adalah perusahaan yang bergerak dibidang percetakan. perusahaan ini memiliki kantor pusat yang terletak di kota Pekanbaru dan memiliki lantai produksi yang berada di pallas. Dalam proses pekerjaan di PT. Jingga Perkasa Printing mengandung potensi bahaya yang dapat menimbulkan kecelakaan kerja. Hal ini dapat dilihatdari tahun 2013sampai tahun 2015 yaitu 75 kasus kecelakaan pada pekerjaan bagian Perawatan, Pemotongan, Pelubangan, dan Printing yang berupa kecelakaan ringan,sedang, dan berat.Oleh karena itu perlu adanya pencegahan kecelakaan kerja yang dilakukan dengan mengidentifikasi faktor-faktor yang menjadi penyebab. Tujuan penelitian ini untuk mengetahui tingkat pencapaian manajemen kecelakaan kerja (SMK2) yaitu dengan menggunakan Frequency Rate, dan Saverity Rate. Untuk penyebab kecelakaan kerja diidentifikasi dengan menggunakan metode FTA (Fault Tree Analysis), kemudian analisa 5S (Seiri, Seiton, Seiso, Seiketsu, dan Shitsuke) yang dilakukan pada area produksi di PT. Jingga Perkasa Printing.Hasil dari analisa di atas digunakan untuk upaya pencegahan kecelakaan kerja di PT. Jingga Perkasa Printing dengan memberikan usulan perbaikan sesuai dengan 5S.
\end{abstract}

Kata Kunci : FTA, Frequency Rate, 5S, Saverity Rate

\section{Pendahuluan}

Dalam pelaksanaan K3 sangat dipengaruhi oleh 3 faktor utama yaitu manusia, bahan, serta metode yang digunakan, yang artinya ketiga unsur tersebut tidak dapat dipisahkan dalam mencapai penerapan K3 yang efektif dan efisien. Sebagai bagian dari iImu Kesehatan Kerja, penerapan K3 dipengaruhi oleh 4 faktor yaitu adanya organisasi kerja, administrasi K3, pendidikan dan pelatihan, Penerapan prosedur dan peraturan di tempat kerja, serta pengendalian lingkungan kerja.Keselamatan dan kesehatan kerja mempunyai peranan penting dalam perusahaan, karena dampak kecelakaan dan penyakit yang diakibatkan karena kurangnya kepedulian keselamatan dan kesehatan kerja tidak hanya merugikan tenaga kerja, tetapi juga merugikan perusahaan.

Analisa kecelakaan memperlihatkan bahwa untuk setiap kecelakaan ada faktor penyebabnya.Sebab-sebab tersebut bersumber kepada alat-alat mekanik dan lingkungan serta kepada manusianya sendiri.Untuk mencegah kecelakaan, penyebab-penyebab ini harus dihilangkan. $85 \%$ dari sebab-sebab kecelakaan adalah faktor manusia.Maka dari itu usaha-usaha keselamatan selain ditujukan kepada teknik mekanik juga harus memperhatikan secara khusus aspek manusiawi (Mufarokhah, 2006).

PT. Jingga Perkasa Printing Merupakan perusahaan yang bergerak dalam bidang percetakan, dimana kertas diolah menjadi koran yang bernama Harian Vokal. Harian Vokal didirikan oleh bapak H. Yusrizal Koto yang beralamat di jalan Pallas. Perusahaan ini sudah termasuk salah satu perusahaan percetakan ternama untuk wilayah Pekanbaru dan sekitarnya, dimana koran hasil produksi didistribusikan ke sejumlah daerah-daerah seperti Rokan Hulu, Rokan Hilir, Dumai, dan Duri. Meskipun demikian tidak bisa di pungkiri masih saja terjadi kecelakaan kerja di perusahan ini, Berikut merupakan potensi yang mengakibatkan kecelakaan kerja di PT. Jingga perkasa Printing.

Tabel 1. Jenis Pekerjaan di PT. Jingga Perkasa

\begin{tabular}{|l|c|c|c|}
\hline \multirow{2}{*}{$\begin{array}{c}\text { Jenis } \\
\text { Pekerjaan }\end{array}$} & \multicolumn{3}{|c|}{ Periode Tahun } \\
\cline { 2 - 4 } & $\mathbf{2 0 1 3}$ & $\mathbf{2 0 1 4}$ & $\mathbf{2 0 1 5}$ \\
\hline Perawatan & 12 & 14 & 28 \\
\hline Pemotongan & 22 & 18 & 15 \\
\hline Pelubangan & 15 & 11 & 17 \\
\hline Printing & 19 & 14 & 15 \\
\hline Total & 68 & 57 & 75 \\
\hline
\end{tabular}

(Sumber: PT. Jingga Perkasa Printing, 2016) 


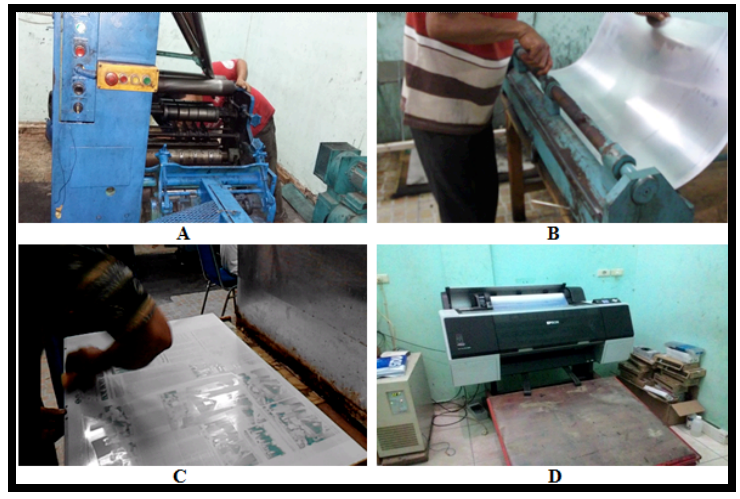

Gambar 1. Potensi yang mengakibatkan kecelakaan pada PT. jingga perkasa printing

Pada Gambar 1 dapat lihat bahwa area produksi seperti pada bagian $\mathrm{A}, \mathrm{B}, \mathrm{C}$, dan D yang ada di PT. Jingga Perkasa Printing itu tidak adanya penggunaan konsep 5S seperti ringkas, rapi, resik, rawat, dan rajin. Padahal konsep 5S itu sangat penting pada perusahaan. Dengan menerapkan konsep $5 \mathrm{~S}$ perusahaan dapat meminimalisir tingkat kecelakaan dan bagaimana cara penataan area-area produksi dengan baik.

Berdasarkan survey yang telah dilakukan, kecelakaan kerja yang sering terjadi pada area produksi PT. Jingga Perkasa Printing adalah pada bagian mesin gulung kertas seperti yang terlihat pada gambar bagian A. Dimana pada bagian mesin gulung kertas tersebut biasannya para pekerja lalai atau lengah dalam melakukan perawatan mesin tersebut, sehingga tangan pekerja sering terjepit pada bagian mesin.akibatnya tangan pekerja tersebut ada yang luka dan ada juga yang mengalami patah pada jarinnya. Dengan kejadian tersebut maka bisa diketahui bahwa penggunaan dari $5 \mathrm{~S}$ itu belum sama sekali di mengerti atau diterapkan oleh pekerja. Selain itu, juga pada bagian pemotong seperti yang terlihat pada gambar bagian B sering terjadi kecelakaan yang diluar dugaan seperti kejatuhan tuas pemotong yang biasa digunakan sebagai pemotong alas polyster.Dan akibatnya pekerja mengalami luka pada bagian kepala ataupun pada tangan yang kejatuhan pipa tersebut.

Pada gambar bagian $\mathrm{C}$ juga dapat dilihat pekerja di bagian pelubangan polyster pada saat memposisikan polyster yang akan dilubangi tidak menggunakan sarung tangan. Kemudian potongan dari polyster tersebut tidak mempunyai alat penampung, Oleh sebab itu pekerja sering tergores akibat terkena polyster tersebut. Karena pada bagian pinggir polyster jika tergores pada tangan dan kaki akan mengakibatkan luka. Kemudian, pada gambar bagian D bisa dilihat bahwa pekerja juga sering tersengat listrik pada saat proses printing beroperasi, karena letak dari kabel-kabel yang tidak beraturan. Akibatnya pekerja yang tersengat listrik berarus tinggi atau tegangan tinggi akan mengalami lebam dan lemas. Maka dari itu konsep 5S seperti ringkas, rapi, resik, rawat, dan rajin harus dipahami oleh pekerja. Dengan mengetahui konsep tersebut maka akan meminimalisir kecelakaan.

Dimana dalam kurun waktu satu tahun terakhir yaitu pada tahun 2015 sudah terjadi kecelakaan kerja sebanyak 75 kecelakaan yang terjadi, dimana dari kecelakaan kerja tersebut 3 orang diantaranya mengalami patah tulang, ataupun tergolong kecelakaan berat, sementara 11 orang harus menjalani perawatan di rumah, dan sisanya termasuk ke dalam kecelakaan ringan. Berikut ini adalah paparan data kecelakaan kerja daritahun 2013-2015 pada PT. Jingga Perkasa Printing.

Tabel 2. Jenis kecelakaan di PT. jingga perkasa printing tahun 2013-2015

\begin{tabular}{|l|c|c|c|}
\hline \multirow{2}{*}{$\begin{array}{c}\text { Jenis } \\
\text { Kecelakaan }\end{array}$} & \multicolumn{3}{|c|}{ Periode Tahun } \\
\cline { 2 - 4 } & $\mathbf{2 0 1 3}$ & $\mathbf{2 0 1 4}$ & $\mathbf{2 0 1 5}$ \\
\hline Ringan & 46 & 45 & 61 \\
\hline Sedang & 12 & 5 & 0 \\
\hline Berat & 10 & 7 & 14 \\
\hline Total & 68 & 57 & 75 \\
\hline
\end{tabular}

(Sumber: PT. Jingga Perkasa Printing, 2016)

Berikut adalah grafik kecelakaan kerja berdasarkan jenis pekerjaan dan jenis kcelakaan pada PT. Jingga Perkasa Printing pada tahun 20132015.

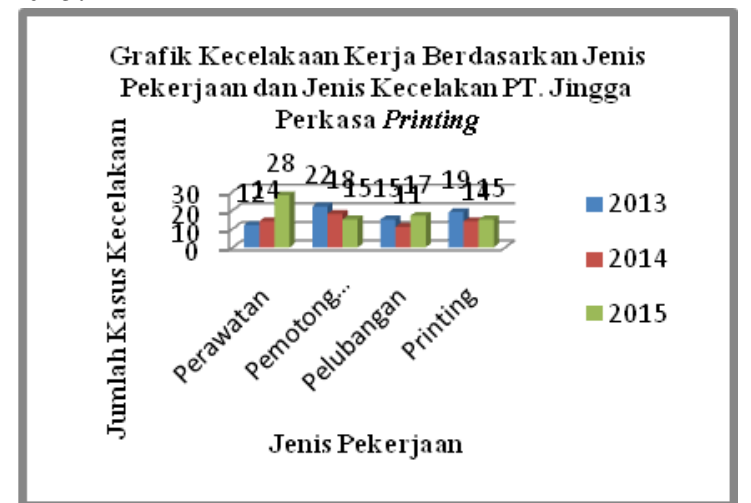

Gambar 2.Grafik kecelakaan kerja berdasarkan jenis pekerjaan dan jenis kecelakaan pada PT. jingga perkasa printing pada tahun 2013-2015

Berdasarkan Tabel 1 dan Tabel 2 menunjukan bahwa paparan data jenis pekerjaan serta jenis kecelakaan yang ada di PT. Jingga Perkasa Printing, dimana seperti yang terlihat, terdiri dari perawatan, pemotongan, pelubangan, dan printing. Dari tahun 2013-2015 bahwa angka tertinggi yang mengalami kecelakaan kerja yaitu pada tahun 2015 dimana berjumlah dari 75 kasus kecelakaan kerja yang meliputi 61 jenis kecelakaan ringan, dan 14 adalah jenis kecelakaan berat. Kejadiaan tersebut akan menimbulkan kerugian bagi perusahaan dan pekerja, maka dari itu meskipun 
dalam jumlah yang kecil, kecelakaan seharusnya dilakukan penanggulangan serta pencegahan yang sesuai.

Dari Grafik pada Gambar 2. terlihat bahwa kecelakaan kerja dari tahun 2013-2015 mengalami peningkatan. Seperti pada bagian perawatan terlihat ditahun 2013 mengalami kasus kecelakaan sebanyak 12 kasus, kemudian tahun 2014 mengalami 14 kasus kecelakaan, dan tahun 2015 meningkat drastis yaitu sebanyak 28 kasus kecelakaan. Kemudian pada bagian pemotongan ditahun 2013 sebanyak 22 kasus kecelakaan, tahun 2014 sebanyak 18 kasus, dan tahun 2015 berjumlah 15 kasus kecelakaan kerja. Pada bagian pelubangan kecelakaan kerja pada tahun 2013 berjumlah 15 kasus, Kemudian tahun 2014 jumlah kasus kecelakaan yaitu 11 kasus, Tahun 2015 berjumlah 17 kasus kecelakaan. Dan yang terakhir pada bagian printing jumlah kecelakaan di tahun 2013 sebanyak 19 kasus kecelakaan, tahun 2014 berjumlah 14 kasus, kemudian tahun 2015 sebanyak 15 kasus kecelakaan kerja. Oleh sebab itu perlu adanya tindakan usulan yang sesuai dengan kategori 5S dimana dari segi penataan mesin-mesin maupun dari kebersihan serta kerapian selama proses produksi berlangsung begitu juga dengan budaya para pekerjannya.

Dari semua kasus kecelakaan kerja tersebut tentu berdampak negatif terhadap perusahaan baik dari target produksi maupun dari segi biaya pengeluaran yang harus di tanggung oleh perusahaan yang bersangkutan demi menjaga kelancaran serta kemajuan perusahaan. Berikut ini merupakan target produksi yang ada di PT. Jingga Perkasa Printing tahun 2013-2015.

Tabel 3.Target produksi PT. jingga perkasa printing per tahun

\begin{tabular}{|c|c|c|c|c|}
\hline No & Tahun & $\begin{array}{c}\text { Target } \\
\text { Produksi/thn }\end{array}$ & $\begin{array}{c}\text { Jumlah } \\
\text { Produksi/thn }\end{array}$ & Keterangan \\
\hline 1 & 2013 & 750.000 Eks & 715.000 Eks & $\begin{array}{c}\text { Tidak } \\
\text { Tercapai }\end{array}$ \\
\hline 2 & 2014 & 750.000 Eks & 722.000 Eks & $\begin{array}{c}\text { Tidak } \\
\text { Tercapai }\end{array}$ \\
\hline 3 & 2015 & 750.000 Eks & 700.000 Eks & $\begin{array}{c}\text { Tidak } \\
\text { Tercapai }\end{array}$ \\
\hline
\end{tabular}

(Sumber: PT. jingga perkasa printing, 2016)

Berdasarkan Tabel 3 menunjukan target produksi koran yang ada pada PT. Jingga Perkasa Printing dari tahun 2013-2015, menurut hasil wawancara pihak produksi target produksi dalam pertahun tidak mengalami perubahan, namun biasannya target produksi tidak tercapai apabila karyawan tidak bisa memenuhi target sesuai ketetapan pertahun nya karena disebabkan oleh berbagai hal seperti akibat dari kecelakaan kerja dan harus cuti untuk beberapa bulan atau beberapa minggu. Dari data target produksi yang ada pada Tabel 3 dapat dilihat bahwa dari tahun 2013-2015 jumlah produksi yang ada di PT. Jingga Perkasa Printing tidak dapat memenuhi target produksi, seperti yang terlihat pada tahun 2013 hanya mampu memproduksi sebanyak 715.000 eksemplar koran dalam pertahun nya dikarenakan adannya kasus kecelakaan kerja yang berjumlah 68 kasus kecelakaan.Kemudian pada tahun 2014 dapat memproduksi 722.000 eksemplar koran karena adannya 57 kasus kecelakaan kerja. Namun, pada tahun 2014 mengalami kenaikan pada jumlah produksi koran. Dan tahun 2015 hanya dapat memproduksi koran sebanyak 700.000 eksemplar koran dikarekan adannya 75 kasus kecelakaan kerja dan pada tahun 2015 terjadi angka tertinggi kecelakaan berat yang berjumlah 14 kasus dari tahun sebelumnya. Perusahaan ini akan mengurangi pasokan ke sejumlah daerah apabila target produksi tidak tercapai.Berdasarkan hasil wawancara, berikut adalah biaya yang di tanggung oleh PT. Jingga Pekasa Printing dalam menangani kasus kecelakaan kerja dalam pertahunnya.

Tabel 4. Biaya kecelakaan pekerja PT. jingga perkasa printing per tahun

\begin{tabular}{|c|c|c|}
\hline Tahun & $\begin{array}{c}\text { Biaya Kecelakaan } \\
\text { Pekerja }\end{array}$ & $\begin{array}{c}\text { Jumlah } \\
\text { Kasus }\end{array}$ \\
\hline 2013 & Rp.138.000.000,00 & 68 \\
\hline 2014 & Rp.118.000.000,00 & 57 \\
\hline 2015 & Rp.205.000.000,00 & 75 \\
\hline
\end{tabular}

(Sumber: PT. Jingga Perkasa Printing, 2016)

Dari Tabel 4 bisa dilihat bahwa biaya yang di tanggung oleh perusahaann dalam pertahunnya mengalami peningkatan. Seperti pada tahun 2013 biaya yang harus dikeluarkan yaitu sebesar $\mathrm{Rp}$. 138.000.000,00 untuk menangani 68 kasus kecelakaan. Kemudian di tahun 2014 biaya yang dikeluarkan sebesar Rp. 118.000.000,00 untuk menangani 57 kasus kecelakaan kerja. Di tahun 2015 mengalami peningkatan yang sangat drastis dari tahun sebelumnya karena menanggung dari 75 kasus kecelakaan yang ada pada PT. Jingga Perkasa Printing yang harus mengeluarkan biaya sebesar Rp. 205.000.000,00. Oleh sebab itu untuk meminimalisir kecelakaan kerja yang ada pada perusahaan perlu adannya perbaikan dalam cara kerja maupun dalam area produksi. 5S merupakan upaya yang dilakukan guna memberikan usulan dalam melakukan segala jenis pekerjaan atau pun aktifitas produksi dengan memanfaatkan segala sesuatunya dengan secara baik. 


\section{Tinjauan Pustaka}

\section{Kecelakaan Kerja}

Kecelakaan adalah kejadian yang tidak terduga dan tidak diharapkan. Tidak terduga, oleh karena dibelakang peristiwa itu tidak terdapat unsur kesengajaan, apalagi dalam bentuk perencanaan. Kejadian peristiwa sabotase atau tindakan kriminal diluar lingkup kecelakaan kerja. Kecelakaan tidak diharapkan oleh karena peristiwa kecelakaan disertai kerugian material ataupun penderiataan dari yang paling ringan sampai kepada yang paling berat. Kecelakaan adalah suatu kejadian yang tidak diinginkan, datang secara langsung dan tidak terduga, yang dapat menyebabkan kerugian pada manusia, perusahaan, masyarakat dan lingkungan. Kecelakaan akibat kerja adalah kecelakaan berhubungan dengan hubungan kerja di perusahaan.

Kecelakan tidak terjadi kebetulan, melainkan ada sebabnya. Sebab kecelakan harus diteliti dan ditemukan agar untuk selanjutnya dengan tindakan korektif yang ditujukan kepada penyebab itu serta dengan upaya preventif lebih lanjut. Kecelakaan dapat dicegah agar tidak terulang kembali. Ada dua golongan penyebab kecelakaan kerja. Golongan yang pertama adalah faktor mekanis dan lingkungan, yang meliputi segala sesuatu selain faktor manusia. Golongan yang kedua adalah faktor manusia itu sendiri yang merupakan penyebab kecelakaan. Untuk menentukan sebab dari suatu kecelakaan dilakukan analisis kecelakaan (Suma'mur, 2009).

\section{Metode FTA (Fault Tree Analysis)}

Metode ini berkembang sekitar tahun 1995, oleh US air force disebabkan banyaknya kejadian kecelakaan udara. Dilakukan oleh Bell Laboratories. Saat ini FTA telah banyak digunakan di berbagai industri, termasuk dibidang konstruksi. Bidang industri digunakan untuk mengetahui atau pencatatan kegiatan yang dilakukan. Kegagalan dalam industri dapat diketahui akibat adanya hubungan sebab akibat dari catatan atau pelaporan kegiatan yang dilakukan, sedangkan bidang konstruksi digunakan untuk kejadian kecelakaan kerja. Metode ini mempermudah orang yang membaca kegagalan produk yang dibuat suatu pabrik atau instansi. Diagram pohon sering pula digunakan dalam menganalisa kejadian kecelakaan merupakan modifikasi dari diagram pohon yang dipakai dalam perhitungan yang selanjutnya disebut fault tree (pohon kegagalan) (Sutanto, 2010).

FTA (Fault Tree Analysis) adalah suatu metode analisa resiko kuantitatif dengan model grafik dan logika yang menampilkan kombinasi kejadian yang memungkinkan yaitu rusak atau baik, yang terjadi dalam sistem, aplikasinya dapat mencakup suatu sistem, equipment dan sebagai analis. Dengan menggunakan analisa ini maka dapat diketahui faktor - faktor dan juga kombinasi penyebab yang dapat menyebabkan terjadinya kecelakaan. Analisa ini dapat digunakan pada proyek Pembangunan Gedung Perkantoran dan Perkuliahan, mengingat pada proyek banyak sekali keadaan yang dapat menimbulkan kecelakaan. Untuk itu sangat diperlukan analisa metode ini untuk mengetahui penyebab-penyebab dan kombinasi yang tersembunyi yang dapat menyebabkan terjadinya kecelakaan sehingga diharapkan kecelakaan tersebut dapat dihindari (Sutanto, 2010).

\section{Metode 5S (5S Methods)}

Program 5S (Seiri, Seiton, Seiso, Seiketsu dan Shitsuke) merupakan dasar bagi mentalitas karyawan untuk melakukan perbaikan (improvement) dan juga untuk mewujudkan kesadaran mutu (quality awareness). 5S adalah sebuah pendekatan dalam mengatur lingkungan kerja, yang pada intinya berusaha mengeliminasi waste sehingga tercipta lingkungan kerja yang efektif, efisien dan produktif. Sedangkan (Hirano dikutip oleh Agustin, 2013) mendefinisikan 5S sebuah alat untuk membantu mengungkapkan masalah dan bila digunakan secara canggih, dapat menjadi bagian dari proses pengendalian visual dari sebuah sistem lean yang direncanakan dengan baik.

5S sendiri merupakan singkatan dari Seiri (Sort), Seiton (Straighten), Seiso (Shine), Seiketsu (Standardize), dan Shitsuke (Sustain). Dalam bahasa Indonesia diterjemahkan sebagai 5R yang berarti Ringkas, Rapi, Resik, Rawat, Rajin. 5S sangatlah penting karena merupakan pondasi dalam membuat suatu proses menjadi sependek mungkin, mengurangi biaya produksi, output yang berkualitas dan mengurangi timbulnya kecelakaan dengan adanya kondisi yang lebih baik (Agustin, 2013).

5S/5R merupakan konsep yang sangat sederhana berasal dari Jepang yaitu Seiri, Seiton, Seiso, Seiketsu dan Shitsuke yang dalam bahasa Indonesia adalah Ringkas, Rapi, Resik, Rawat dan Rajin (Rimawan, 2015).

Pada dasarnya 5S/5R merupakan proses perubahan sikap dengan menerapkan penataan dan kebersihan kerja guna tercapainya Keselamatan dan Kesehatan Kerja (K3) di lingkungan bangunan gedung perkantoran, pabrik dan laboratorium. Sebagaimana diketahui, kondisi tempat kerja mencerminkan perlakuan seseorang terhadap pekerjaannya. Untuk itu dalam penelitian ini pokok permasalahan yang akan penulis bahas adalah bagaimana perusahaan menerapkan $5 \mathrm{~S}$ guna menjaga Keselamatan dan Kesehatan Kerja yang dapat mengoptimalkan target produksi berdasarkan permintaan konsumen tepat waktunya dan 
profesionalisme perusahaan tetap terjaga baik guna memuaskan konsumen yang pada akhirnya diperoleh loyalitas konsumen (Rimawan, 2015).

\section{Metode Penelitian}

Metodologi penelitian merupakan deskripsi dari seluruh rangkaian kegiatan yang dilaksanakan selama proses penelitian, yakni dari awal kegiatan sampai dengan akhir penelitian. Metodologi penelitian digunakan untuk mengarahkan serta mempermudah proses pemecahan masalah dan menganalisa hasil pengolahan melalui manajemen penelitian yang baik sehingga penelitian yang dilakukan dapat menjadi lebih berkualitas. Setiap tahapan dalam metodologi penelitian adalah bagian yang penting sehingga harus dilakukan dengan baik dan teliti.Adapun uraian langkah-langkah penelitian tersebut adalah sebagai berikut.

1. Menghitung tingkat pencapaian Sistem Manajemen Kecelakaan Kerja (SMK2) Perhitungan tersebut yaitu menggunakan Frequency Ratemerujuk ke Rumus (2.1) dan juga Saverity Rate merujuk Rumus (2.2).

2. Metode FTA (Fault Tree Analysis)

Dimana menegetahui apa ssaja penyebab dari kecelakaan -kecelakaan kerja yang ad pada perusahaan tersebut.

3. Metode $5 \mathrm{~S}$

a. Seiri (Ringkas)

Menganalisis sistem kerja pada stasiun sehingga dapat dilakukan pemilihan dengan tepat.

b. Seiton (Rapi)

Menganalisis penataan peralatan atau barang yang tepat sehingga mudah dalam pengambilan atau pencarian.

c. Seiso (Resik)

Menganalisis tentang permasalahn kebersihan yang ada pada setiap stasiun.

d. Seiketsu (Rawat)

Menganalisis sistem agar dapat menjaga seiri, seiton, seiso agar lebih memantapkan sistem keja.

e. Shitsuke (Rajin)

Menganalisa peningkatan kemampuan yang lebih optimal dalam menerapkan 5S.

f. Memberikan usulan sesuai dengan $5 \mathrm{~S}$ Bagaimana usulan perbaikan yang harus dibuat pada perusahaan tersebut guna meminimalisir kecelakaan kerja.

\section{Hasil dan Pembahasan}

\section{Menentukan Sistem Manajemen Kecelakaan Kerja (SMK2)}

Dalam pengolahan data ini, Dengan menentukan pencapaian sistem manajemen kecelakaan kerja (SMK2) melalui perhitungan FrequencyRate, dan Saverity Rate. Tujuannya dilakukan perhitungan FrequencyRate, dan Saverity Rate adalah untuk melihat pencapaian apakah mengalami peningkatan atau penurunan kecelakaan kerja di PT. Jingga Perkasa Printing.

\section{Perhitungan Frequency Rate}

Data yang digunakan untuk menghitung FrequencyRate adalah banyak kecelakaan dan total jam kerja manusia. Adapun tujuannya adalah untuk melihat potensi kasus kecelakaan dalam kurun waktu tertentu. Pada Frequency Rate ini menggunakan per 200.000 jam kerja. Berikut merupakan rekapitulasi perhitungan Frequency Rate

Tabel 5. Rekapitulasi Perhitungan Frequency Rate

\begin{tabular}{|c|c|c|c|c|}
\hline \multirow{2}{*}{$\begin{array}{c}\text { Jenis } \\
\text { Pekerjaan } \\
\text { Bagian }\end{array}$} & \multicolumn{3}{|c|}{ Frequency Rate (FR) } & \multirow{2}{*}{ Total } \\
\cline { 2 - 4 } & $\mathbf{2 0 1 3}$ & $\mathbf{2 0 1 4}$ & $\mathbf{2 0 1 5}$ & \\
\hline Perawatan & 56 & 71 & 124 & $\mathbf{2 5 1}$ \\
\hline Pemotongan & 102 & 91 & 67 & $\mathbf{2 6 0}$ \\
\hline Pelubangan & 70 & 56 & 76 & $\mathbf{2 0 2}$ \\
\hline Printing & 88 & 71 & 67 & $\mathbf{2 2 6}$ \\
\hline Total & $\mathbf{3 1 6}$ & $\mathbf{2 8 9}$ & $\mathbf{3 3 4}$ & \\
\hline
\end{tabular}

Tabel 5 menunjukan bahwa tingkat frekuensi atau kekerapan kecelakaan yang paling tinggi yaitu terjadi pada tahun 2015. Ditahun 2013 angka kecelakaan paling tinggi berada pada bagian pekerjaan pemotongan, dengan jumlah kecelakaan yaitu lebih dari 100 kecelakaan dalam setiap 200.000 jam dari total jam kerja manusia 43.200 jam kerja. Kemudian pada bagian pekerjaan perawatan, pelubangan, dan printing mengalami kasus kecelakaan lebih dari 50 kasus dalam setiap 200.000 jam kerja.

Pada tahun 2014 angka kecelakaan tertinggi juga terdapat pada bagian pekerjaan pemotongan, yaitu lebih dari 90 kasus kecelakaan dalam setiap 200.000 jam dari total jam kerja manusia yaitu 39.600 jam. kemudian pada bagian pekerjaan seperti perawatan, pelubangan, dan printing mengalami 
kasus kecelakaan lebih dari 50 kasus kecelakaan. Di tahun 2015 jumlah kecelakaan paling tinggi yaitu pada bagian perawatan, yaitu lebih dari 100 kasus kecelakaan dalam setiap 200.000 jam dari total jam kerja manusia sebanyak 45.000 jam kerja. Kemudian Angka kecelakaan pada bagian pekerjaan seperti pemotongan, pelubangan, dan printing yaitu lebih dari 60 kasus kecelakaan.

Dari uraian diatas angka kecelakaan paling tinggi yaitu berada pada bagian pekerjaan pemotongan, dimana pada bagian pekerjaan tersebut mengalami kecelakaan lebih dari 250 kasus kecelakaan dalam jangka waktu 3 tahun dengan total jam kerja manusia yang berbeda-beda. Kemudian, dari semua jenis bagian pekerjaan angka kecelakaan paling tinggi dalam jangka waktu 3 tahun yaitu pada tahun 2015 yang mencapai lebih dari 300 kasus kecelakaan dalam setiap 200.000 jam dari jumlah total jam kerja manusia sebesar 45.000 jam.

\section{Perhitungan Saverity Rate}

Data untuk menghitung nilai severity rate diperoleh dari jumlah total hilangnya hari kerja per 1.000 jam manusia. Tujuannya adalah untuk melihat potensi hari kerja hilang dalam jangka waktu tertentu akibat kasus kecelakaan kerja. Dibawah ini merupakan hari kerja dan jumlah jam kerja yang hilang pada PT. Jingga Perkasa Printing

Tabel 6. Hari kerjadan jumlah jam kerja hilang

\begin{tabular}{|c|c|c|c|c|c|c|}
\hline \multirow{3}{*}{$\begin{array}{c}\text { Jenis } \\
\text { Pekerjaan } \\
\text { Bagian }\end{array}$} & \multicolumn{6}{|c|}{ Tahun } \\
\hline & \multicolumn{2}{|c|}{2013} & \multicolumn{2}{|c|}{2014} & \multicolumn{2}{|c|}{2015} \\
\hline & Hari & Jam & Hari & Jam & Hari & Jam \\
\hline Perawatan & 13 & 78 & 10 & 60 & 15 & 90 \\
\hline Pemotongan & 29 & 174 & 22 & 132 & 33 & 198 \\
\hline Pelubangan & 9 & 54 & 11 & 66 & 10 & 60 \\
\hline Printing & 10 & 60 & 9 & 54 & 12 & 72 \\
\hline
\end{tabular}

Berikut ini adalah rekapitulasi dari perhitungan Saverity Rate.

Tabel 7. Rekapitulasi perhitungan saverity rate

\begin{tabular}{|c|c|c|c|c|}
\hline \multirow{2}{*}{$\begin{array}{c}\text { Jenis } \\
\text { Pekerjaan } \\
\text { Bagian }\end{array}$} & \multicolumn{3}{|c|}{ Saverity Rate(SR) } & \multirow{2}{*}{ Total } \\
\hline & 2013 & 2014 & 2015 & \\
\hline Perawatan & 2 & 2 & 2 & 6 \\
\hline Pemotongan & 4 & 3 & 4 & 11 \\
\hline Pelubangan & 1 & 2 & 1 & 4 \\
\hline Printing & 1 & 1 & 2 & 4 \\
\hline Total & 8 & 8 & 9 & \\
\hline
\end{tabular}

Pada tahun 2013 sampai 2015 semakin banyak hari kerja yang hilang terutama di pekerjaan bagian pemotongan, hal ini dapat merugikan perusahaan. Pada tahun 2015 dilakukan perhitungan tingkat keparahan yang mengakibatkan hilangnya potensi jam kerja yaitu Severity Rate 198 Jam. Angka ini menunjukan bahwa dalam setiap 1.000 jam kerja, dari total jam kerja manusia pada tahun 2015 sebesar 45.000 jam yang bekerja di PT. Jingga Perkasa Printing terdapat potensi jam hilang sebanyak 198 jam atau 33 hari setiap tahunnya. Tingkat keparahan tahun sebelumnya yaitu tahun 2014 lebih rendah di banding tahun 2013 dan 2015. Pada bagian perawatan, pelubangan, dan printing memiliki tingkat keparahan cendrung bervariasi dari tahun ketahun. Angka ini perlu di lakukan pengambilan tindakan oleh pihak perusahaan agar meminimasi kecelakaan kerja yang dapat menyebabkan hilangnya jam kerja karyawan.

Dari uraian diatas, jumlah jam hilang pada bagian pekerjaan pemotongan dari tahun 2013 sampai dengan tahun 2015 berjumlah lebih dari 10 jam kerja yang hilang dalam setiap 1.000 jam kerja. Kemudian dari semua jenis pekerjaan, jumlah jam kerja yang hilang di tahun 2015 memiliki angka paling tinggi yaitu lebih dari 8 jam kerja yang hilang dalam setiap 1.000 jam kerja.

\section{Mencari Penyebab Kecelakaan dengan Menggunakan Metode (FTA)}

Suatu kecelakaan dapat terlihat dengan mengetahui apa saja penyebab dari kecelakaan tersebut. Dengan menggunakan pohon kesalahan (fault tree) dapat diketahui apa-apa saja yang cenderung menjadi penyebab dari terjadinnya kecelakaan pada suatu perusahaan.Berikut merupakan paparan dari pohon kesalahan (fault tree) yang ada di PT. Jingga Perkasa Printing.

Tabel 7. Potensi kecelakaan

\begin{tabular}{|c|c|c|c|}
\hline No & $\begin{array}{c}\text { Jenis } \\
\text { Pekerjaan }\end{array}$ & $\begin{array}{c}\text { Akibat } \\
\text { Kecelakaan }\end{array}$ & $\begin{array}{c}\text { Penyebab } \\
\text { Kecelakaan }\end{array}$ \\
\hline \multirow{4}{*}{1} & \multirow{4}{*}{ Perawatan } & \multirow{4}{*}{$\begin{array}{c}\text { Tangan } \\
\text { Terluka dan } \\
\text { patah }\end{array}$} & $\begin{array}{l}\text { Tidak } \\
\text { memakai } \\
\text { APD } \\
\end{array}$ \\
\hline & & & $\begin{array}{l}\text { Kurangnya } \\
\text { Pengetahuan }\end{array}$ \\
\hline & & & Pekerja lalai \\
\hline & & & Tidak fokus \\
\hline \multirow{4}{*}{2} & \multirow{4}{*}{ Pemotongan } & \multirow{4}{*}{$\begin{array}{c}\text { Kejatuhan } \\
\text { tuas } \\
\text { pemotong } \\
\text { pada Kepala } \\
\text { dan luka pada } \\
\text { tangan }\end{array}$} & $\begin{array}{l}\text { Pekerja } \\
\text { lengah dan } \\
\text { lalai }\end{array}$ \\
\hline & & & $\begin{array}{l}\text { Kurang } \\
\text { penataan } \\
\text { ruang } \\
\end{array}$ \\
\hline & & & Tidak fokus \\
\hline & & & $\begin{array}{l}\text { Tidak } \\
\text { konsentrasi }\end{array}$ \\
\hline
\end{tabular}




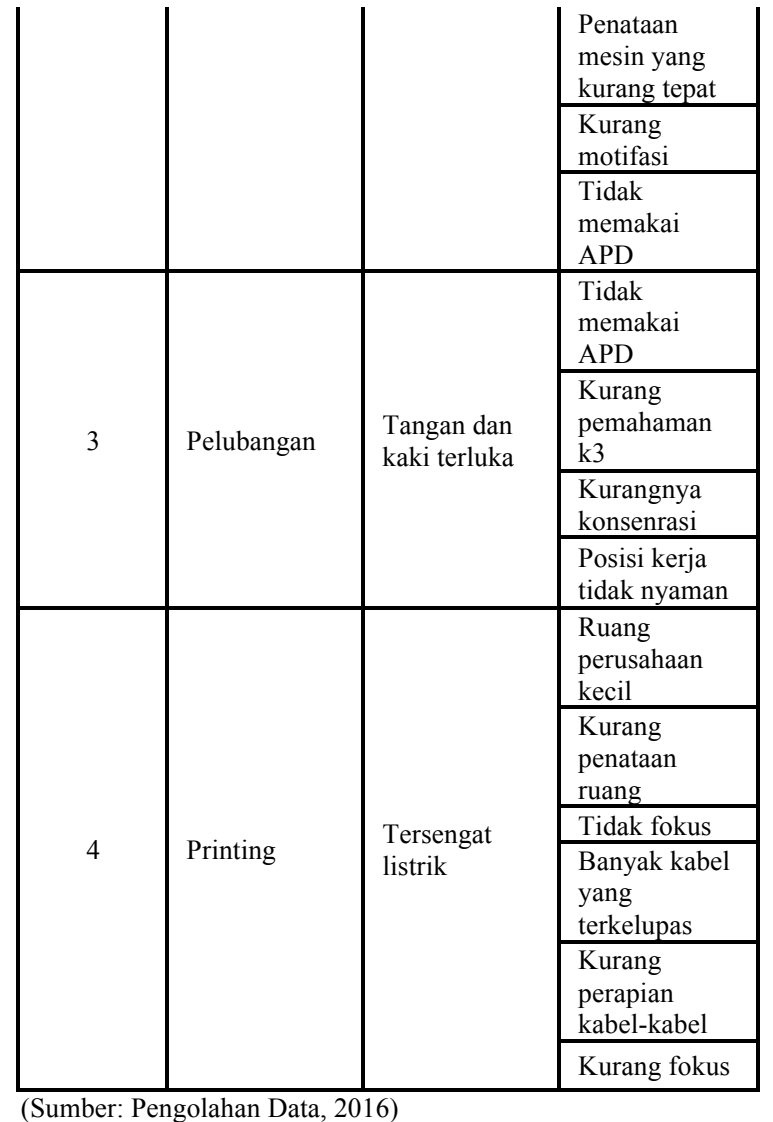

Mencari penyebab kecelakaan menggunakan metode Fault Tree Analysis (FTA) yang digunakan untuk mendeteksi adanya akar penyebab suatu masalah kecelakaan kerja yang terjadi di PT. Jingga Perkasa Printing, pembuatan dimulai dari kejadian puncak kemudian dikembangkan pada kejadian awal dan dapat dilihat pada Gambar 4

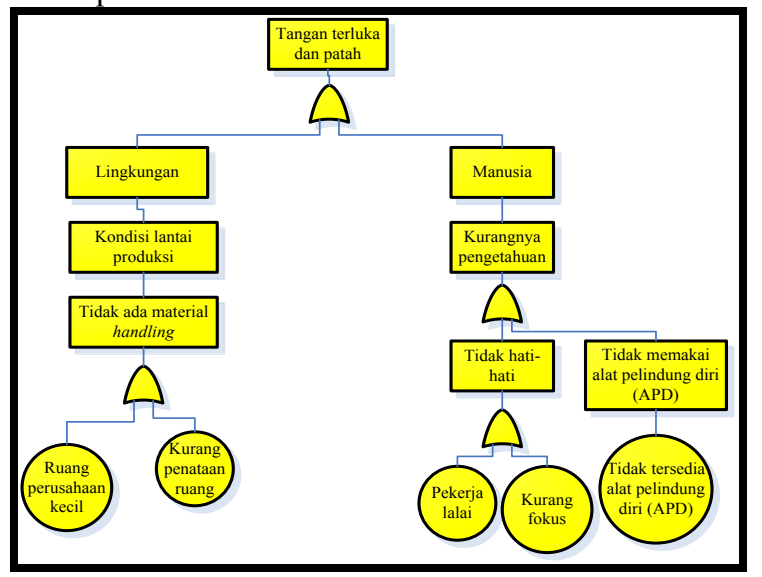

Gambar 4. Model fault tree tangan terluka dan patah

Dari Fault Tree di atas dapat dilihat bahwa penyebab dari tangan terluka dan patah yaitu ditinjau dari segi lingkungan dan manusia. Adapun dari lingkungan dapat dilihat bahwa kondisi lantai produksi yang kotor sehingga pekerja tidak nyaman pada saat bekerja. Kemudian tidak ada material handling yang membantu pekerja untuk menjangkau bagian mesin paling atas pada saat proses perawatan, penyebab dari tidak adannya material handling yaitu ruang yang ada pada perusahaan kecil, kemudian kurangnya dalam penataan ruang sehingga susah dalam menempatkan material handling.

Dari segi manusia dapat dilihat bahwa penyebab dari tangan terluka dan patah yaitu kurangnya pengetahuan tentang keselamatan dalam bekerja, sehingga pekerja tidak hati-hati karena lalai dan tidak fokus pada saat bekerja. Kemudian pekerja tidak memakai alat pelindung diri karena pihak perusahaan tidak menyediakan alat pelindung yang seharusnya dipakai oleh pekerja.

\section{Metode 5S pada Perawatan}

\section{Seiri}

Dengan membiasakan ataupun menerapkan manajemen untuk membedakan antara barang yang masih dipakai dengan barang yang tidak terpakai lagi adalah tindakan yang sesuai dengan metode $5 \mathrm{~S}$ yaitu seiri. Pada PT. Jingga Perkasa Printing pekerjaan perawatan kurang menerapkan dari unsur seiri (ringkas). Ketika pekerja melakukan perawatan pada mesin, masih ada barang yang tidak digunakan terletak pada samping bagian mesin produksi, seperti dinamo mesin dan tutupnya. Dengan letak barang yang tidak sesuai dan memiliki bobot yang berat, membuat pekerja menjadi tidak leluasa dan tidak nyaman pada saat melakukan pekerjaannya. Barang yang memiliki bobot berat dan berada pada samping mesin produksi akan mengakibatkan kecelakaan kerja seperti pekerja terjepit, tangan terluka, dan patah saat ingin memindahkan.

\section{Seiton}

Seiton diartikan sebagai pengelompokan dari setiap barang yang diletakkan pada tempatnya, misalnya suatu barang mempunyai jenis dan ukuran yang berbeda maka barang tersebut harus di letakkan sesuai dengan jenis dan ukuran masing-masing. Dengan menerapkan unsur seiton maka dalam mencari suatu benda akan mudah ditemukan. Pada pekerjaan perawatan yang ada pada PT .Jingga Perkasa Printing penerapan unsur seiton belum diaplikasikan karena masih berantakan dengan barang yang tidak digunakan, seperti dinamo mesin dan tutupnya. Dengan adannya dinamo mesin dan tutupnya yang sudah tidak dipakai akan membuat pekerja menjadi tidak leluasa dan dapat menimbulkan kecelakaan kerja seperti tangan terjepit, tangan terluka, dan patah saat ingin memindahkan. Oleh sebab itu kesiapan tempat kerja yang baik akan menghasilkan kerja yang optimal apabila pengaplikasian seiton dilakukan. 
Seiso

Prinsip dari seiso adalah membersihkan tempat dan lingkungan kerja agar terhindar dari kotoran. Dengan keadaan lingkungan kerja yang bersih akan membuat pekerja menjadi nyaman dan tidak merasa stress pada saat berada ditempat kerja. Ketika pekerja melakukan perawatan di bagian mesin produksi, dinamo mesin dan tutupnya yang sudah tidak digunakan sangat kotor dan berdebu. Apabila kotoran dan debu terhirup oleh pekerja, maka akan mempengaruhi kesehatan pekerja pada saat melakukan pekerjaannya. Dengan demikian, unsur seiso harus benar-benar diaplikasikan pada area kerja demi menjaga kelancaran serta kenyamanan pekerja saat proses perawatan berlangsung.

\section{Seiketsu}

Seiketsu merupakan sebuah kegiatan dimana setiap orang harus berupaya mempertahankan suatu kebiasaan yang baik terhadap suatu barang. Pada PT. Jingga Perkasa Printing penerapan unsur seiketsu sudah diaplikasikan pada pekerjaan perawatan. Dimana pekerja melakukan perawatan rutin pada mesin produksi yang digunakan sebagai proses produksi koran. Hal ini harus di optimalkan dengan baik agar mesin yang digunakan tidak mengalami kerusakan. Dengan penerapan seiketsu dapat meminimalisir potensi kecelakaan seperti tangan terluka dan patah.

\section{Shitsuke}

Prinsip dari shitsuke yaitu menjaga kebiasaan pekerja agar lebih disiplin ditempat kerja. Disiplin bisa dilakukan dengan cara mengembangkan kebiasaan yang baik. Pada bagian perawatan penerapan shitsuke belum adannya penerapan, ketika melakukan perawatan mesin produksi pekerja sering lalai dan tidak fokus saat bekerja sehingga mengakibatkan pekerja mengalami cidera seperti tangan terluka dan patah. Kemudian belum membiasakan diri memakai alat pelindung diri (APD) sebagai pengaman saat bekerja.

\section{Kesimpulan}

Berdasarkan hasil penelitian yang telah dilakukan di PT. Jingga Perkasa Printing, maka secara umum dapat disimpulkan sebagai berikut :

1. Tingkat pencapaian sistem manajemen kecelakaan kerja di PT. Jingga Perkasa Printing adalah sebagai berikut :

a. Tingkat kekerapan (Frequency Rate)

Berdasarkan dari perhitungan frequency rate yang telah dilakukan pada bab sebelumnya diketahui bahwa pencapaian kecelakaan kerja yang ada di PT. Jingga Perkasa Printing mengalami peningkatan. Hal ini dapat dilihat pada tahun 2013 dengan jumlah 316 kasus kecelakaan, tahun 2014 jumlah kasus kecelakaan yaitu 289, dan tahun 2015 berjumlah 334 kasus kecelakaan. Angka tersebut didapatkan dari perhitungan frequency rate dengan jumlah jam kerja yaitu 200.000 .

b. Tingkat keparahan (Saverity Rate)

Dari perhitungan saverity rate yang telah dilakukan diketahui bahwa pencapaian jam kerja akibat dari kecelakaan yang ada di PT. Jingga Perkasa Printing mengalami peningkatan. Dapat dilihat pada tahun 2013 jumlah jam kerja yang hilang akibat dari kecelakaan yaitu 8 jam, tahun 2014 jumlah jam kerja hilang yaitu 8 jam, dan ditahun 2015 jumlah jam kerja yang hilang karena kecelakaan yaitu 9 jam. Hal ini diketahui dengan menggunakan perhitungan jam kerja produktif yaitu 1000 jam.

2. Penyebab kecelakaan kerja yang ada di PT. Jingga Perkasa Printing berdasarkan metode Fault Tree Analysis (FTA) adalah:

\begin{tabular}{|c|c|c|}
\hline No & Pekerjaan & Penyebab Kecelakaan \\
\hline 1 & Perawatan & 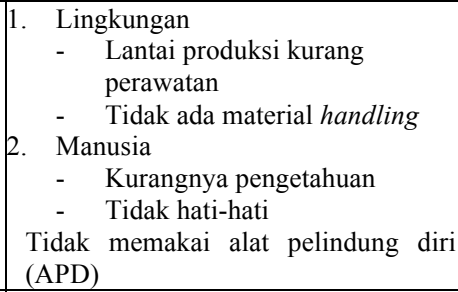 \\
\hline 2 & Pemotongan & \begin{tabular}{|ll} 
1. & Lingkungan \\
& $-\quad$ Lantai produksi kurang \\
& perawatan \\
- & Letak mesin tidak tepat \\
2. & Manusia \\
- & Kurangnya kehati-hatian \\
- & Pekerja lalai atau ceroboh \\
- & Pekerja terlalu letih \\
- & Tidak memakai alat pelindung \\
& diri (APD)
\end{tabular} \\
\hline 3 & Pelubangan & \begin{tabular}{|ll}
1. & Lingkungan \\
- & Kondisi lantai produksi \\
- & Tidak nyaman \\
2. & Manusia \\
- & Posisi kerja tidak nyaman \\
- & Pemahaman k3 kurang \\
- & Tidak hati-hati dalam bekerja \\
- & Tidak ada alat pelindung diri \\
\end{tabular} \\
\hline 4 & Printing & $\begin{array}{ll}\text { 1. } & \text { Manusia } \\
\text { - Tidak hati-hati } \\
\text { 2. } \\
\text { Lingkungan } \\
\text { - Lantai produksi berantakan } \\
\text { 3. } \\
\begin{array}{l}\text { Mesin } \\
\text { - Kabel-kabel banyak yang } \\
\quad \text { terkelupas }\end{array}\end{array}$ \\
\hline
\end{tabular}


3. Usulan perbaikan berdasarkan metode $5 \mathrm{~S}$ yang diberikan di PT. Jingga Perkasa Printing adalah sebagai berikut :

a. Usulan $5 \mathrm{~S}$ pada bagian perawatan

- Membedakan tempat yang sesuai pada peralatan yang akan digunakan dan tidak digunakan kembali, seperti dinamo mesin yang seharusnya tidak berada pada bagian tersebut dan di letakkan pada tempat yang sesuai.

- Membuat material handling sebagai alat bantu yang digunakan pekerja dalam menjangkau mesin bagian atas pada saat proses perawatan berlangsung.

- Meletakkan alat pembersih yaitu sapu, dan kemoceng untuk membersihkan mesin maupun lantai produksi setelah proses perawatan selesai.

- Membuat wadah sebagai penampung kotoran yaitu debu yang ada pada mesin.

- Lebih memantapkan pada saat perawatan agar lebih maksimal untuk mencapai hasil yang lebih optimal.

- Membiasakan pekerja agar memakai alat pelindung diri pada saat proses perawatan berlangsung.

- Menanamkan jiwa disiplin dan bertanggung jawab pada diri pekerja agar setiap perbaikan dapat diaplikasikan secara optimal.

- Membuat display yang berkaitan dengan keselamatan dalam bekerja, agar pekerja dapat memahami arti dari keselamatan diri dalam bekerja.

- Memberikan motivasi dengan memberikan bonus dan menjalin hubungan baik agar pekerja tidak jenuh dalam melakukan pekerjaan yang menjadi tanggung jawabnya.

b. Usulan $5 \mathrm{~S}$ pada bagian pemotongan

- Menentukan tempat pembuangan dari hasil pemotongan polyster agar tidak berserakan pada area pemotongan.

- Membedakan tempat dari barang yang tidak digunakan dan yang masih digunakan agar tidak mengganggu pada saat bekerja.

- Merapikan bekas potongan agar terkumpul dengan baik dan mudah dalam proses pembuangan ke dalam tempat pembuangan.

- Memberikan display agar pekerja terbiasa meletakkan alat yang telah digunakan pada tempatnya.

- Membersihkan sisa dari potongan polyster agar tidak berserakan pada lantai yang dapat mengganggu pekerja dalam bekerja.
- Membersihkan sisa polyster yang ada pada bagian alat pemotong agar bersih dari kotoran.

- Melakukan perawatan rutin yang lebih maksimal terhadap alat pemotong yang digunakan dalam proses pemotongan. Hal tersebut untuk menghindari pengeroposan dan korosi pada alat pemotong.

- Memberikan pemahaman terhadap pekerja betapa pentingnya memakai alat pelindung diri, terutama bagian tangan.

\section{Daftar Pustaka}

[1] Agustin, Purnama, "Implementasi $5 S$ pada $C V$. Valasindo menggunakan Pendekatan Ergonomi Partisipatori, “ Jurusan Teknik Industri Universitas Islam Indonesia. Yogyakarta. 2013

[2 Kinanti. A, “ Pengaruh Motivasi Dan Lingkungan Kerja Terhadap Kinerja Karyawan Hotel Muria Semarang, " Skripsi, hal. 26, 2012

[3] Suma'mur, P.K. 'Hiegiene Perusahaan dan Kesehatan Kerja (Hiperkes)" Halaman. 405-411. Sagung Seto, Jakarta. 2009

[4] Somad. I, “ Teknik Efektif Dalam Membudayakan Keselamatan \& Kesehatan Kerja " Halaman 93-94. Dian Rakyat, Jakarta. 2013 